italicized. These problems do not detract from the essential argument or the importance of this book, however.

In terms of substantive critique, there is so little Balkan military history in English that a curious reader is indeed left with a sizable wish list of topics and sources that could have been built into a volume such as this. Above all, one might wish to see at least some inclusion of topics from the new military history to supplement this traditional account, and more analysis of what made the commanders, especially Oskar Potiorek on the Austrian side and Živojin Mišić on the Serbian side, such a colossal failure and success, respectively.

In sum, this worthy volume has appeared at the right time to feed our interest in, and add to our understanding of, the Great War, which was tearing Europe apart precisely a hundred years ago. Lyon's study is concrete and adds new knowledge to our considerations, in contrast to many new books on World War I that are primarily interpretive. Above all the author has endeavored to add Serbian-language sources to a chapter of military history usually fueled overwhelmingly by German-language sources, and to shift the center of gravity in our discussions of the Serbian side in 1914 away from Gavrilo Princip and the machinations of the Black Hand and onto the surprising twists and turns of the intense fighting in northern Serbia. The author has achieved these goals, and Balkan specialists can be glad that the number of successful monographs on important trends in our area of specialty is growing, if slowly.

John K. Cox

North Dakota State University

Europe since 1989: A History. Philipp Ther. Trans. Charlotte Hughes-Kreutzmüller. Princeton: Princeton University Press, 2016. xi, 425 pp. Notes. Bibliography. Photographs. \$35.00, hard bound.

doi: 10.1017/slr.2017.198

This book offers an interesting new perspective. "The comparative analysis moves from East to West," the author promises in the Preface, "and not the other way around, as is common in the traditional, occidentalist historiography of Europe" (xi). Instead of analyzing the role of the west in the collapse of communism in 1989 and the transformations that followed, it promises an investigation of the impact of the collapse and transformation of the east to the west. This is an innovative idea. Unfortunately, the author did not fulfill his promise. We do not learn about the impact of the east to the west. The only exception is Germany. But the impact of 1989 on Germany was made by reunification. Other countries are not discussed.

Instead, and this is itself a good achievement, we get a detailed description and analysis about the causes, consequences, and impact of the peaceful revolution of 1989 on eastern Europe. This is mostly based on the huge existing literature and debates. The best original contribution of the author is in presenting the huge gap between the prosperous big cities and the backward countryside and the history of the region in the first decades of the twenty-first century: the best boom before 2008 and the worst bust after it. The focus is on neoliberalism, which guided and determined the transformation of the east.

The greatest question, the impact of eastern enlargement on the EU, is missing. The EU is only marginally mentioned, mostly its influence on transformation by neoliberal prescriptions and a new "Marshall Aid" plan. But what was the influence of the acceptance of eleven former eastern communist countries on the EU? Even its most eminent outcome, the creation of an economic backyard for the west is missing. 
Unlike the USA and Japan, western Europe did not have such a backyard. Now, its corporations got the possibility to build up a huge network of branches, subsidiaries, and value chains in the east, which made them competitive again on the world market against the USA and Japan.

The other central question is whether it was right to include eleven eastern countries as full members of the European Union with their rather different economic levels, business cultures, and political backgrounds. Or was Giscard d'Estaing right when he prophesized that this enlargement will be the end of the EU? Would it have been better to keep this region in an outside, connected status, but not give it full membership, as was suggested but immediately rejected? These questions are totally missing. Instead, the author broadly covers the non-acceptance of Ukraine. After the introduced new Neighborhood Policy (2003), Ukraine, stated the author, "found itself in the same boat as Lebanon, Jordan, Egypt, and a dozen other North African and post-Soviet countries" (317). One should hear that further eastern enlargement would be suicidal for the EU. Even the previous ones turned to be questionable.

The Great Recession after 2008 that hit the east very hard is well discussed. But the authoritarian turn, first in Putin's Russia and then the "Orbanization" of a large part of the former Soviet Bloc, the so-called Visegrad countries, especially Hungary and Poland and its impact on Europe and the EU, would have required a deep analysis. This became a central question about the impact of the post-1989 east on the west.

The author is right that the age of neoliberalism is strongly questioned after 2008, and its challenge, state capitalism (best represented by China and Russia), is "not only looming on the horizon but has already arrived in the EU" (335). Has it arrived to the core of Europe as well? Is it a real alternative? Under neoliberalism the book presents the EU as forcing austerity measures on several member countries after 2008: "Angela Merkel will be perceived as an advocate of asocial rather than a social market economy" (337). The negative effects of the austerity policy are evident. This question, however, is more complex than how it was presented. Irresponsible fiscal policy, spending beyond their means by governments and citizens' alike, and silently accepting tax evasion and widespread corruption in most of the Mediterranean and some of the eastern countries, are not acceptable within the EU. The "educative" role of austerity is thus not negligible for the peripheral countries and especially for the creation of a more homogenous and working EU.

The book can claim positive achievements by presenting a quarter of a century of central and east European history, but it did not realize what its author promised and does not cover the history of Europe after 1989.

IVAN T. BEREND $U C L A$

\section{A Contemporary History of Exclusion: The Roma Issue in Hungary from 1945 to}

2015. By Balász Majtényi and György Majtényi. Budapest: Central University Press, 2016. viii, 242 pp. Notes. Bibliography. Index. Illustrations. Photographs. $\$ 60.00$, hard bound.

doi: 10.1017/slr.2017.199

The Roma entered Hungary in the $13^{\text {th }}$ and $14^{\text {th }}$ centuries and quickly became respected as soldiers, metalsmiths, musicians, and equine specialists. But after Ottoman forces moved into the region, the Hungarian Roma were seen as "incendiaries, soldiers or spies" of the Turks, as I have described in my book A History of the Gypsies of Eastern /Europe and Russia, $2^{\text {nd }}$ edition (71). Such prejudicial views 